\title{
Selected aspects of integrated environmental management
}

\author{
Terézia Pošiváková',A-F, Rudolf Hromada' ${ }^{1, E-F}$, Ján Pošivák ${ }^{2, A-F}$, Ladislav Molnár ${ }^{3, E-F}$, \\ Jarmila Harvanová ${ }^{4, E-F}$ \\ ${ }^{1}$ Department of the Environment, Veterinary Legislation and Economy, University of Veterinary Medicine and Pharmacy, \\ Kosice, Republic of Slovakia \\ ${ }^{2}$ Clinic for Ruminants, University of Veterinary Medicine and Pharmacy, Kosice, Republic of Slovakia \\ ${ }^{3}$ Clinic for birds and exotic animals, University of Veterinary Medicine and Pharmacy, Kosice, Republic of Slovakia \\ ${ }^{4}$ University Hospital L. Pasteur Kosice, I. Internal Clinic, Kosice, Republic of Slovakia \\ $A$ - Research concept and design, B - Collection and/or assembly of data, C - Data analysis and interpretation, \\ $D$ - Writing the article, E-Critical revision of the article, F- Final approval of article
}

Pošiváková T, Hromada R, Pošivák J, Molnár L, Harvanová J. Selected aspects of integrated environmental management. Ann Agric Environ Med. 2018; 25(3): 403-408. doi: 10.26444/aaem/80908

\begin{abstract}
Ibstract
Current trends in environmental care are characterised by the principles of comprehensiveness, integration, interdisciplinarity and transregionality. It is in this spirit that the methodological, legislative and economic instruments develop, and this whole trend is referred to using the term 'environmental management'. Environmental management constitutes a set of technical instruments and methods for managing the environment, based upon an identification of the environmental aspects of products, activities and services of any type of organisation, with the aim to adopt and implement effective proactive measures to reduce their negative impact on the environment. These measures, along with their level, relate to an organisation's possibilities, the market's pressure on it, and primarily with the organisation's management's awareness, maturity and ability to anticipate the introduction of stricter requirements. Environmental management, in the industrial production and service sectors, is one of the the most effective instruments for achieving the priority goal, which is to minimise the negative impact of production activities on the individual elements of the environment as part of the global trend of reducing the negative impact of human activity on the environment. The objective of this article is to indicate possibilities to improve the environment through the basic principles and techniques of integrated environmental management.
\end{abstract}

\section{Key words}

environment, environmental management, agriculture, life cycle assessment, industry, sustainability, social factors

\section{INTRODUCTION}

Under public pressure, environmental protection has become a part of economic policy, and a separate area of environmental policy has arisen. There is an apparent direct connection between the economic system and the environment [1], and an apparent basic impact and possibilities of environmental policy on the process of its acting upon the economic system [2]. Environmental management constitutes a set of technical instruments and methods for managing the environment, based on an identification of the environmental aspects of products, activities and services of any type of organisation, with the aim of adopting and implementing effective proactive measures to reduce their negative impact on the environment $[3,4]$. These measures, along with their level, relate to an organisation's possibilities, the market's pressure on it, and primarily with the organisation's management's awareness, maturity and ability to anticipate the introduction of stricter requirements [5]. Timely decision-making, based on continual environmental improvement, allows organisations to adapt more easily to the conditions and requirements implied by the goals and measures of environmental policy, whether at the national or international level [6-8]. One of the cornerstones of integrated management in the field

Address for correspondence: Terézia Pošiváková, University of Veterinary Medicine and Pharmacy in Kosice, Komenského 73, 04181 Košice, Slovak Republic

E-mail: terezia.posivakova@uvlf.sk

Received: 22.10.2017; accepted: 30.11.2017; first published: 24.09.2018 of environment is environmental management, which, by virtue of its strategic management of environmental impact, contributes to a better quality of life [9].

Basic environmental management principles by Sujová [10]. The rapid global expansion of industrial production on the one hand, and public pressure to protect the environment on the other, has resulted in the adoption and gradual introduction of numerous environmental activities that have led from defining a global environmental strategy to carrying out environmental audits in various production and others sectors [11-12].

Environmental management. This is a company management system focused on environmental protection and creation within the interactions of permanently sustainable development at global, regional and local level $[13,14]$. It stems from the need to carry out the EU's Sixth Framework Programme for the environment in the field of training experts for implementing environmental principles and environmental policy $[15,16]$. Environmental management seeks to find a solution as to how to manage business activities in order that they do not cause environmental degradation [17]. Through purposeful improvement in individual processes, a business can contribute not only to a better environment, but also to reducing its business costs (by reducing its waste, energy, water and gas consumption, or emissions), which will be positively reflected in its profits $[18,19]$. 
Environmental policy. A set of concepts, strategies and tactics, as well as specific methods and ways to solve environmental problems. At the time of its creation, environmental policy only focused on environmental protection and the protection of certain natural resources, and did not turn its attention to the wider context of human activities until later [20]. Presently, the permanently sustainable development strategy, also called the 'Prevention Strategy', is the foundation of environmental policy. The goal of this strategy is the maximum possible prevention at the place of origin, of the formation of substances and occurrences with a negative environmental impact. By Suová [10] environmental policy is also based on these three principles:

- prevention: prevention of the formation of pollution is cheaper than elimination of effects;

- integration: impact and measures ought to be examined in an integrated way at all levels of implementation;

- cautiousness: it is necessary to monitor and check effects over the long term and take into account the cumulative effect showing later.

Promotion, implementation and realisation of environmental policy is the subject and the main task of environmental management [10].

Environmental management instruments. A whole host of environmental management instruments arose during the period of environmental management development, e.g. environmental audits, environmental management systems, environmental assessment and product labelling, ecobalances, environmental product profile, etc. These instruments arose mainly as voluntary internal initiatives within businesses and organisations. They now influence policy and product regulation in European Union countries and other countries in the world [10]. Among the basic environmental instruments are:

- product-oriented instruments;

- process-oriented instruments.

\section{Product-oriented instruments}

Environmental product labelling (ECO Labelling). Governed in the Slovak Republic by Act No. 469/2002 on Environmental Product Labelling. The purpose of an environmental label is to promote production development and product consumption with lesser adverse environmental effects during the entire lifetime of a product $[21,22]$. The main advantages of an environmental label are: positive information for consumers, credibility, clarity, public involvement and full compliance with the law and technical standards.

Environmental product life cycle assessment examines the environmental aspects and environmental impact of a product during its entire lifetime, i.e. from the time of obtaining raw materials, through production, use and consumption, to disposal of waste from the product $[23,24]$. The overall level of product quality is then characterised in terms of optimisation of raw material consumption, reduction in energy intensity, minimisation of waste generation, harmlessness to consumer health, reuse of waste from products, safety during product disposal, etc [25-27]. This instrument is closely linked to the available environmental technologies which ensure the effectiveness of production environmentalization.
Integrated product policy focuses on products and services and their environmental aspects. The goal of integrated product policy is to achieve permanently sustainable development focused on reducing the environmental impact of production and products $[28,29]$. The integrated perspective focuses on various aspects, include:

- lifetime cycle: focuses on environmental burdens during the entire life cycle of a product or service;

- environmental elements: focuses on all elements of the environment;

- instruments: traces the various stages in the life cycles of products and services, and uses various instruments to attain this level;

- areas: exploits various policy areas in which a multitude of factors influence environmental issues.

Process-oriented instruments. Process-oriented instruments express environment quality by changing the approach to managing those individual processes within a business that greatly burden the environment $[33,34]$. A systematic approach to environment protection must be the subject of any business strategy. The following instruments are process-oriented:

Environmental Management System (EMS), and the EcoManagement and Audit Scheme (EMAS), are systems based on the principles of continuous improvement of businesses' relationship with the environment, environmental burden reduction and environment enhancement. This system is built around ISO standards of the 14000 series [22, 35]. This voluntary instrument allows businesses the possibility to be competitive and improve their overall public image.

Environmental auditing is an integral part of an environmental management system, based on a comprehensive assessment of a business' environmental concept implementation [29]. It is an instrument for monitoring and checking the functioning of an environmental management system which allows discovering deficiencies in the system and proposing remedial measures to remove deficiencies [36].

Environmental management accounting is a system of records of all environmental costs expended in the field of environment $[37,38]$. This system allows detailed monitoring of costs related to environmental pollution.

Environmental profile evaluation is a business management instrument which is to assist in the process of environmental profile improvement. An environmental profile consists of a businesses' environmental management system's measurable results in terms of its control of its environmental aspects, based on the business' environmental policy, goals and target values [37]. An environmental profile evaluation is a process, planned and implemented using suitable environmental indicators that allow measuring, analysing and determining an environmental profile in relation to prescribed criteria [38].

Clean production is continuous application of an integral preventive environmental protection strategy to precesses, products and services with the aim to increase their efficiency and reduce risks to humans and the environment [39]. In the case of production processes, it means a more 
efficient use of raw materials and energy, exclusion of toxic and hazardous materials, prevention of waste generation and pollution at the source [40]. In the case of products (products and services), a clean production strategy focuses on reducing environmental impact within their life cycle from development to use.

Using these voluntary environmental instruments, it is possible to achieve positive environmental and economic results $[41,42]$. In terms of the efficiency and cost-effectiveness of production system management, and by using these voluntary instruments, we can present the results of those production companies which have achieved considerable success in the field of environment. Among the most significant indicators of effective use of environmental instruments are [43]:

- reduction in material and energy intensity,

- reduction in pollutants,

- reduction in a business' environmental costs.

Legislative and systemic security of environmental management. Environmental policy has become an integral part of the legislative system in recent years. In addition to laws to protect the environment, it is imposed by various regulations and directives, while use of internal business environmentally-oriented measures is also gradually growing $[10,44]$. Implementation of environmentally-oriented management systems is closely linked to quality management systems according to ISO standards [45]. In the early 1990s, the International Organization for Standardisation (ISO) created environmental management system schemes (EMS) containing elements which any EMS must satisfy [35]. Models of these schemes are widely applicable to all types of business and organisation. In 1993, ISO recognised the need to standardise environmental management instruments and formed a standardisation committee which produces standards (so-called ISO) for individual environmental management instruments. The effectiveness of EMS could thereby be evaluated on the basis of compliance with an accepted directive $[35,43,47]$.

International ISO 14000 standards specify the basic requirements of environmental management. They do not define specific criteria for the environment, instead, they require an organisation to form its environmental policy and goals and take into account its significant environmental impact. The standards focus on those aspects which the organisation can itself control and which it can influence through its activities. The standards focus of the basic elements of a managements system, instruments, methods a procedures based on a dynamic and cyclic process plan, performance, control, evaluation. The environmental management system created according to ISO is called ISO $14001[47,48]$.

\section{ENVIRONMENTAL MANAGEMENT STRUCTURE AND MAIN PRICIPLES}

Principle 1) Commitment and policy. Environmental policy is a statement by an organisation on its intentions and principles regarding overall environmental conduct, providing a framework for activities and for setting out longterm and short-term environmental goals [49]. A decision made by top management on introducing environmental management systems, and on subsequent acceptance of an official obligation and its declaration, is a complex and serious process requiring an assessment of the business' overall situation. An assessment of a business' internal situation is a comprehensive review of its situation, on the basis of which the top management gains information allowing it, while taking all external factors into consideration, to issue a declaration stating that it undertakes to continuously improve its environmental profile [50]. The basic procedure in such an assessment of the internal situation a business with an anticipated result is based on judging the following aspects [51]:

- the actual state of the business-environment relationship and on fulfilment of the government environmental policy;

- the activities, production or products that may affect the environment;

- chemical, physical and biological factors that may or do affect the environment;

- contribution to causing environmental problems (local, regional or global);

- possibilities to take remedial measures.

Various methods of assessment, such as EPE, ESAP, or an analysis of the state of the environment, can be used to obtain an assessment of the relationship between a business and the environment. An analysis must be thoroughly prepared and proceeded with, in accordance with a specified schedule which is targeted and to the point. An analysis is performed by a team of experts in various specialisations so that the individual professions are all represented, while the team is led by a person appointed by top management. This leader is given an authorisation and responsibilities, and reports directly to the top leadership. Also, he typically manages the process of EMS implementation and the environment unit. By formulating its environmental policy, a business explains its strategy, intentions and principles underlying its environmental activities which are based on the principles of permanently sustainable development in the context of the government environmental policy [52].

Principle 2) Planning. Environmentally-oriented planning is a conscious management activity which consists in specifying and defining environmental goals, and in determining tasks and methods required to fulfil the declared environmental policy [10]. In order to carry out planning, it is necessary to take into account the internal and external environment and its impact on an organisation's activities, and to identify all environmental aspects and environmental impact.

An environmental aspect is defined as an element of an organisation's activity, products or services which may affect the environment [53].

Environmental impact is defined as an adverse or a favourable change in the environment that is entirely or partially implied by an organisation's activities, products or services [53].

The relationship between an environmental aspect and an environmental impact is practically that of cause and effect. The procedure of identifying aspects and impact can be divided into four basic steps. Based on their recognition, long-term and short-term environmental goals to be achieved by a business in a certain period of time are determined [54]. 
A long-term environmental goal is an overall and, if possible, quantifiable environmental goal implied by environmental policy, which the organisation itself specifies and wishes to achieve.

A short-term environmental goal is a detailed and, if possible, quantifiable requirement for conduct applicable by an organisation or its part, implied by long-term environmental goals, which is to be set out and fulfilled so that these longterm environmental goals are achieved [55]. Environmental goals can be orientated towards [10, 37]:

- reduction in waste and in exhaustion of resources;

- reduction in/elimination of the release of pollutants into the environment [56];

- product design so as to minimise its impact on the environment during production, use and disposal;

- operational management of raw materials' environmental impact;

- minimisation of significant adverse environmental impact of new projects;

- raising environmental awareness among employees and the public.

In their specification, we may characterise, for instance:

- the amount of consumed raw materials/energy;

- the amount of emissions, such as $\mathrm{CO}_{2}$;

- the amount of particular pollutants, such as nitrogen oxides $(\mathrm{NOx})$, sulphur dioxide $\left(\mathrm{SO}_{2}\right)$, carbon monoxide (CO), hydrocarbons ( $\mathrm{HC})$, lead $(\mathrm{Pb})$ or hydrofluorocarbons (HFCs) [57, 58];

- the percentage of recycled waste;

- the percentage of recycled material used for packaging;

- generated waste per number of finished products.

Incorporating a solution to environmental problems characterised by the impact assessment criterion into short-term or long-term environmental goals depends on several factors, i.e. economic, technical, technological and organisational, but the extent and degree of a threat to biotic systems should, however, be crucial [59-62]. The final outcome is a formulation of the Environmental Management System Programme.

The Environmental Management Programme. This can refer to a system securing responsible workers' activities towards achieving long-term and short-term environmental goals [63]. First and foremost, it includes a determination of specific responsibilities for every important organisational position and level along with the means and the time frame [64]. It is a document which clearly and specifically defines an organisation's environmental goals, and describes, for all elements of the business, in a manner that is targeted and to the point, the tasks and responsibilities of all workers involved together with the obligations of all workers, as well as the resources for ensuring comprehensive implementation [65].

Principle 3) Implementation. Judging by practical experience, winning employees for realising top management's intention or commitment to implement and realise EMS, convincing them of the necessity of this step and training them to adopt new habits and responsibilities, is a basic precondition for success. This requirement is fulfilled in the form of training of all employees at all levels of management and non-management staff. The structure, content and scope is usually delivered by the HR Department at the request of the director or the head of the unit through an internal or an external trainer. The system and content of the training is specified according to the level of management and its professional profile, and then separately for other staff. A comprehensive system of employee preparation is connected with professional and qualification requirements and requirements needed to implement best production practice.

The overall process of implementing EMS is a complex one and requires a proactive approach from all management workers along with employee engagement [66]. Good managers at all levels, competence, communication skills, ability to acquire and share information at the right time from and to the right addressee in a suitable form all play an important role in the process. A good company information system should serve this purpose [67,68]. During implementation, it is important to consider not only the internal structure and problems of a business, but also all internal and external factors which may positively affect this process, not least because implementation of the system is expensive [68].

\section{CONCLUSIONS}

The topic of this article is highly relevant, especially due to the continuing efforts to reduce negative impact on the environment in all aspects of social life and production activities. The subject of this article was a summary of the basic aspects of environmental management by means of which it is possible to reduce negative imopact on the environment.

\section{Acknowledgements}

This study was supported by Grant No.: KEGA 003 UVLF$4 / 201$.

\section{REFERENCES}

1. Al Samarrai G, Singh H, Syarhabil M. Evaluating eco-friendly botanicals natural plant extracts as alternatives to synthetic fungicides. Ann Agr Env Med. 2012; 19(4): 673-676.

2. Lozano M, Vallés J. An Analysis of the Implementation of an Environmental Management System in a Local Public Administration. J Environ Manage. 2007; 82(4): 495-511.

3. Mazzi A, Toniolo S, Mason M, Aguiari F, Scipioni A. What are the benefits and difficulties in adopting an environmental management system. J Clean Prod. 2016; 139: 873-885.

4. Paulí EA, André FJ. Standardised environmental management systems as an internal management tool. Res Energy Econ. 2015; 40: 85-106.

5. Babakri KA, Bennett R, Franchetti M. Critical factors for implementing ISO 14001 standard in United States industrial companies. J Clean Prod. 2003; 11: 749-752.

6. Bernardo M, Simon A, Tarí JJ, Molina-Azorín JF. Benefits of management systems integration. J Clean. Prod. 2015; 94: 260-267.

7. Švajlenka J, Kozlovská M, Spišáková M. The benefits of modern method of construction based on wood in the context of sustainability. IJEST. 2017; 14(8): 1591-1602.

8. Demková L, Árvay J, Bobul’ská L, Tomáš J, Stanovič R, Lošák T, Harangozo L, Vollmannová A, Bystrická J, Musilová J, Jobbágy J. Accumulation and environmental risk assessment of heavy metals in soil and plants of four different ecosystem in a former polymetallic ores mining and smelting area Slovakia. J Environ Sci Health, Part A. 2017; 52(5): 479-490. 
9. Adamkovičová A. A tool integrated environmental management EMAS. 2013; 12: 11-17.

10. Sujová A. Environmental management. Eko dizajn. 2013; 8: 1-17.

11. Švajlenka J, Kozlovská M. Modern method of construction based on wood in the context of sustainability. Civ Eng Environ Syst. 2017; 34(2): 127-143.

12. Olívka L', Pástor P, Balog K. Environmental management. Bratislava: STU, 2001. p.139.

13. Campos LMS. Trierweiller AC, Nunes De Carvalho D, Šelih J. Environmental management systems for small companies a study in Southern Brazil. J Clean Prod. 2016; 16(2): 453-460.

14. ISO, 2006. ISO 14040:2006 Environmental Management, Life Cycle Assessment - Principle and Framework. International Organisation for Standardization (ISO), Geneva ( $\mathrm{CH})$.

15. Fura B, Wang Q. The level of socioeconomic development of EU countries and the state of ISO 14001 certification. Qual Quant. 2017; 51(1): 103-119.

16. ISO, 2010. ISO 26000:2010: Guidance on Social Responsibility. International Organisation for Standardization (ISO), Geneva (CH).

17. Demirel P. Kesidou E. Stimulating different types of eco-innovation in the UK government policies and firm motivations. Ecol Econ. 2011; 12(3): 1-37.

18. Engert S, Rauter R, Baumgartner RJ. Exploring the integration of corporate sustainability into strategic management a literature review. J Clean Prod. 2016; 112: 2833-2850.

19. ISO, 2006. ISO 14044:2006 Environmental Management, Life Cycle Assessment - Requirements and Guidelines. International Organisation for Standardization (ISO), Geneva (CH).

20. Guenther E, Hoppe H. Merging limited perspectives. a synopsis of measurement approaches and theories of the relationship between corporate environmental and financial performance. J Ind Ecol. 2014; 18(5): 689-707.

21. Demirel P, Kesidou E. Stimulating different types of eco-innovation in the UK: government policies and firm motivations. Ecol Econ. 2011; 70: $1546-1557$

22. Iraldo F, Testa F, Frey M. Is an environmental management system able to influence environmental and competitive performance. The case of the ecomanagement and audit scheme EMAS in the European Union. J Clean Prod. 2009; 17(16): 1444-1452.

23. Švajlenka J, Kozlovská M. Research on the quality parameters of modern methods of construction based on wood. Proceedings of the 6th International Masaryk Conference; 2015 Dec 12-16; Hradec Králové, Czech Republic. Magnanimitas; 2015.

24. ISO, 2015. ISO 14001: Environmental Management Systems Requirements with Guidance of Use. International Standard Organization, Geneva $(\mathrm{CH})$

25. Franchetti M. ISO 14001 and solid waste generation rates in US manufacturing organizations an analysis of relationship. J Clean Prod. 2011; 19: 1104-1109.

26. ISO - International Organization for Standardization, ISO 14040 International Standard. Environmental management - Life cycle assessment - Principles and framework. Geneva, Switzerland.: International Organisation for Standardization, 2006; 2:20.

27. ISO - International Organization for Standardization, ISO 14044 Environmental Management: Life Cycle Assessment, Life Cycle Impact Assessment. Geneva, Switzerland.: International Organisation for Standardization, 2006;1:46.

28. Goyal P, Rahman Z, Kazmi AA. Corporate sustainability performance and firm performance research. Manag Decis. 2013; 51(2): 361-379.

29. Iraldo F, Testa F, Frey M. Is an environmental management system able to influence environmental and competitive performance? The case of the ecomanagement and audit scheme EMAS in the European Union. J Clean Prod. 2009; 17: 1444-1452.

30. Wu J. Environmental compliance the good, the bad, and the super green. J Environ Manag. 2009; 90: 3363-3381.

31. Kostevšek A, Petek J, Cuček L, Pivec A. Conceptual design of a municipal energy and environmental system as an efficient basis for advanced energy planning. Energy 2013; 60: 148-158.

32. Nakano K. Life-cycle assessment framework for adaptation planning to climate change linking regional climate impact with product design. Int J Life Cycle Assess. 2015; 20: 819-828.

33. Jacquemin L, Pontalier PY, Sablayrolles C. 2012. Life cycle assessment LCA applied to the process industry: a review. Int J Life Cycle Assess. 2012; 8: 1028-1041.

34. Demková L, Bobul’ská L, Árvay J, Jezný T, Ducsay L. Biomonitoring of heavy metals contamination by mosses and liches around Slovinky tailing pond Slovakia. J Environ Sci Health, Part A. 2017; 52(1): 30-36.
35. Morrow D, Rondinelli D. Adopting corporate environmental management system motivations and result of ISO 14001 and EMAS certification. J Eur Manag. 2017; 2: 159-171.

36. Švajlenka J, Kozlovská M. Perception of economic, social and environmental aspects of modern methods of construction. IJAME. 2015; 4(6): 68-77.

37. Annandale D, Morrison-Saunders A, Bouma G. The impact of voluntary environmental protection instruments on company environmental performance. Business Strategy and the Environment 2004; 13: 1-12.

38. ISO, 2016. ISO 37101: Sustainable Development in Communities Management System for Sustainable Development - Requirements with Guidance for Use. International Organisation for Standardization (ISO), Geneva (CH).

39. Yi I, Itsubo N, Inaba Y, Matsumoto K. 2007. Development of the interregional I/O based LCA method considering region-specifics of indirect effects in regional evaluation. Int J Life Cycle Assess. 2007; 12(6): 353-364.

40. Azapagic A, Pettit C, Sinclair, P., 2007. A Life Cycle Methodology for Mapping the Flows of Pollutants in the Urban Environment. Clean Techn. Environ. Policy 2007; 9: 199-214.

41. Angelovičová L, Lodenius M, Tulisalo E, Fazekašová D. Effect of heavy metals on soil enzyme activity at different field conditions in middle spis mining area Slovakia. Bull Environ Contam Toxicol. 2014; 93(6): 670-676.

42. ISO, 2014. ISO 37120: Sustainable Development in Communities - Indicators for City Services and Quality of Life. International Organisation for Standardization (ISO), Geneva (CH).

43. Daddi T, Frey M, De Giacomo MR, Testa F, Iraldo F. Macro-economic and development indexes and ISO14001 certificates a cross national analysis. J Clean Prod. 2015; 108: 1239-1248.

44. Lewandowska A. Environmental life cycle assessment as a tool for identification and assessment of environmental aspects in environmental management systems EMS part 1 methodology. Int J Life Cycle Assess. 2011; 16: 178-186.

45. Oliveira JA, Otavio J, Oliveira J, Aldo R. Ometto AS. Ferraudo MH. Salgado Environmental Management System ISO 14001 factors for promoting the adoption of Cleaner Production practices, J Clean Prod. 2016; 133: 1384-1394.

46. Pojasek R. Quality toolbox developing performance after attaining conformance in your environmental management program. Environ Qual Manag. 2003; 12(3): 97-102.

47. Skouloudis A, Jones K, Sfakianaki E, Lazoudi E, Evangelinos K. EMAS statement benign accountability or wishful thinking insights from the Greek EMAS registry. J Environ Manag. 2013; 128: 1043-1049.

48. Watson M, Emery ART. Environmental management and auditing systems the reality of environmental self-regulation. J Manag Audit. 2004; 19(7): 916-928.

49. Nishitani K, Kaneko S, Fujii H, Komastu S. Are firms voluntary environmental management activities beneficial for the environment and business an empirical study focusing on Japanese manufacturing firms. J Environ Manag. 2012; 105: 121-130.

50. Sebrae e Serviço Brasileiro de Apoio as Micro e Pequenas Empresas, 2015. Business Classification criteria.

51. UNEP. Life Cycle Management a Business Guide to Sustainability. 2007.

52. Ferreira AJD, Lopes MAR, Morais JPF. Environmental management and audit schemes implementation as an educational tool for sustainability. J Clean Prod. 2006; 14: 973-82.

53. Handfield R, Walton S, Sroufe R, Melnyk S. Applying environmental criteria to supplier assessment a study in the application of the analytical hierarchy process. EJOR 2002; 141: 70-87.

54. European Commission. Commission Regulation EC No. 196/2006 of 3 February 2006 amending Annex I to Regulation (EC) No 761/2001 of the European Parliament and of the Council to take account of the European Standard EN ISO 14001:2004, and repealing Decision 97/265/EC. Brussels: European Community; 2006 (OJEC, 4-02-2006, L 32/1).

55. Biondi V, Frey M, Iraldo F. Environmental management systems sme barriers, opportunities and constraints. Greener Management International 2000; 29: 1-23.

56. Bobul'ská L, Fazekašová D, Angelovičová L, Kotorová, D. Impact of ecological and conventional farming system on chemical and biological soil quality indices in a cold mountain climate in Slovakia. Biol Agric Hortic. 2015; 31(3): 205-218.

57. Švajlenka J, Analysis of the transport costs of wooden buildings. Proceedings of the International Conference Juniorstav; Feb 18; Brno, Czech Republic.VUT; 2015. 
58. Švajlenka J, Kozlovská M. Transport costs of prefab wood and brick construction - comparative study. Technical Transactions: Civil Engineering. 2016; 113(1-B): 129-135.

59. Sopkova D, Andrejcakova Z, Vlckova R, Danisova O, Supuka P Ondrasovicova $S$, Petrilla V. Lactate dehydrogenase as a possible indicator of reproductive capacity of boars Indian J Anim Sci. 2015; 85(2): 143-147.

60. Vlčkova R, Valocky I, Lazar G, Sopková D, Maraček I. Histological and ultrasonographic monitoring of folliculogenesis in puerperal ewes after spring lambing. Acta Vet Brno. 2008; 77(1): 65-72.

61. Horňáková L. Hajurka J, Vitková T, Kuricová M. Testosterone levels and testimetry evaluation in dogs. In Proceedings of the International Conference ESDAR. Oxford: Blackwell. 2015; 50(3): 57.

62. Yilmaz O. Hazardous Waste Management System Design for Turkey submitted to Middle East Technical University, Turkey. 2011; 213.
63. Hunt D, Johnson C. Environmental Management Systems Principles and Practice. London: McGraw-Hill, 1996. p.320.

64. Watson M, Emery ART. Environmental management and auditing systems the reality of environmental self regulation. J Manag Audit. 2004; 19(7): 916-928.

65. Darnall N, Jason Jolley G, Handfield R. Environmental management systems and green Supply chain management complements for sustainability Business Strategy and the Environment 2008; 18: 30-45.

66. Mehta K, Chugan PK. Green HRM in pursuit of environmentally sustainable business. Univ J Ind Bus Manag. 2015; 3(3): 74-81.

67. Berchicci L, King A. Postcards from the edge. A review of the business and environment literature. Acad Manag Ann. 2007; 1(1): 513-547.

68. Arimura TH, Hikibi A, Katayama H. Is a voluntary approach an effective environmental policy instrument a case for environmental management systems. J Environ Econ Manag. 2008; 55: 281-295. 